\title{
Accra's Decongestion Policy: Another Face of Urban Clearance or Bulldozing Approach?
}

\author{
Aba O. Crentsil and George Owusu
}

\begin{abstract}
Metropolitan local governments in Ghana, most especially the Accra Metropolitan Assembly (AMA), have adopted and implemented a policy of decongestion of the large metropolitan cities of Ghana in the past decades. This policy has been implemented with the explicit aim of reducing informal activities and their operators in the central business districts (CвDs) and other key areas of the cities. While the implementation of the policy in Accra, Ghana's largest metropolis, has been ad hoc in character, owing to a combination of factors such as limited public support and political liability most especially in election years, the policy in both theoretical and practical terms can be described as representing another form of the much criticised classical 'bulldozing or slum clearance' approach. Bearing in mind the backlash against the bulldozing or slum clearance approach as an unsustainable means for promoting urban development, city authorities have coined the term 'decongestion' as a simplistic approach to clearing areas of the city of Accra they perceive to be undesirable. This chapter reveals wide-ranging negative impacts of these bulldozing approaches on street traders, slum dwellers and other informal operators as well as the political liability of the policy. It also finds that the concept and practice of 'Right to the City' has, to a large extent, been 'back-burnered' as urban informal operators are regarded as not possessing any rights in public spaces, with serious implications for achieving inclusive and sustainable urban development as highlighted in the Sustainable Development Goals and the New Urban Agenda.
\end{abstract}

\section{Introduction}

Recent decades have witnessed a renewed interest in questions of the future of cities and the extent to which cities can shape socio-economic development in general (see UNFPA, 2007; McGranahan et al., 2001). However, nowhere have these questions received greater attention than in the global South, where rapid urbanisation has magnified the environmental impact of cities as the

(C) ABA O. CRENTSIL AND GEORGE OWUSU, 2018 | DOI:10.1163/9789004387942_010

This is an open access chapter distributed under the terms of the prevailing CC-BY-NC License at the time of publication. 
process is occurring within the context of inadequate infrastructure and services, poor planning and weak urban management and governance systems (Owusu and Oteng-Ababio, 2015). In addition, a remarkable feature of urbanisation in the global South is the widening inequalities among the population and the segregation of urban neighbourhoods along economic and income lines (Grant, 2015; Satterthwaite and Mitlin, 2014).

While the causes of these widening inequalities are not the focus of this chapter, we note that this has lately attracted a great deal of attention, both from academics, who have long engaged with radical urban theory, and from grassroots activists, who have been fighting on the ground for an alternative just urbanism' (Kuymulu, 2013a, 924) and a more inclusive urban development that takes account of the needs of peoples with different socio-economic backgrounds. Kuymulu (2013a) adds that the concern for inclusive urban development has also drawn considerable attention from several UN agencies, notably UN-Habitat, UNDP and UNESCO, as well as the World Bank and the International Monetary Fund (IMF), all of which have formed policy outlines to advocate for inclusive urban development. Consequently, concepts such as 'the right to the city', 'inclusive urbanisation', 'just city' and more broadly 'sustainable urbanisation' have come to dominate the policy space on urban development, which has led to fundamentally opposing institutions and ideologies (McGranahan et al., 2016; Mayer, 2012; Schmid 2012; Stanek, 2011; Fainstein, 2010; Harvey, 2008; Lefebvre, 1996 [1967]). This is because, in the view of Kuymulu (2013a, 2013b), concepts such as the right to the city are idealised political ideas with broad-based popular appeal in the face of structural urbanisation challenges and the alienation of a large section of the urban poor in respect of the benefits of urbanisation.

Ghana, a sub-Saharan African country undergoing rapid urbanisation, has largely bought into the idea of the right to the city and inclusive urbanisation, as captured in its national level policies. Indeed, Ghana's national policies such as the National Urban Policy Framework (NUPF) and Action Plan, 2012; National Housing Policy (NHP), 2015; National Spatial Development Framework (NSDF), 2015-2035; and other related national-level policies strongly emphasise urban renewal and the upgrading of slums and other informal settlements, and the promotion of the urban informal economy. However, there seems to be a policy disconnection and a contradictory policy response between the national and city levels with the introduction of a policy at the city level referred to as 'decongestion' (Awumbila et al., 2014). Decongestion policy may be defined as the removal of what city authorities perceive to be 'unwanted' activities and areas within cities in Ghana, or simply, the removal of informal settlers and street traders from public spaces in Ghanaian cities (Onuoha, 2014). 
Disguised as a form of slum clearance, the policy has been implemented, particularly in the Accra metropolis, the national political and economic capital, to deal with ever-growing slums and informal economic activities, especially street trading in inner-city areas. According to Awumbila et al. (2014), growing land scarcity and high land prices have resulted in situations whereby poor, informal settlements are increasingly sited in ecologically sensitive, flood-prone areas and on vacant public lands. They further argue that these settlements develop very quickly, and only attract the attention of city authorities at a much later stage. They add that in the Accra metropolis, a special task force or unit has been established, tasked among other duties, with clearing areas of the city (including slums) that city authorities see as 'undesirable'-all under the concept of city decongestion. Yet no national-level policy, including the National Urban Policy Framework and Action Plan, 2012, advocates city decongestion. All national policies recognise and support the urban informal economy and its operators as well as the need for the upgrading and prevention of slums rather than their removal from the urban landscape.

While the concept of decongestion has been analysed by a few researchers, many of these studies have seen it as a question of the forced eviction of street traders (Broadbent, 2012; Abrokwah, 2013). For example, writing on Accra as a case study, Broadbent $(2012,1)$ argues that 'presented as a way of bringing order to a seemingly chaotic city centre, the mainstay of the [decongestion] policy debate surrounds the forced eviction of street hawkers from unsolicited spaces in the busiest areas of the capital. While this assertion by Broadbent (2012) is partly true, we argue in this chapter that the decongestion policy as pursued by city authorities for the last two decades goes beyond mere forceful eviction of hawkers and street traders from central locations of the city of Accra and other major cities in Ghana. Indeed, a careful analysis of media reports, commentaries by Ghanaian urbanists as well as various media communiques of the Accra Metropolitan Assembly (AMA), the city government in charge of Accra, reveal that though pursued in an ad hoc fashion by city authorities, decongestion has been implemented for a wide variety of reasons. These include promoting the free flow of traffic and easing traffic congestion in inner-city areas, making the city fit to be a '21st Century' city under the Millennium City initiative, beautifying the city to attract tourists, businesses and investments, and making way for new flagship developments including roads and multistorey upscale market stalls/shopping malls. Other reasons cited by city authorities include dealing with perennial floods, as city authorities partly blame unauthorised structures (informal activities) for blocking waterways; reducing the growing incidence of crime, where poor, informal settlements are seen as a haven for criminals; and even, in some cases, dealing with the perceived spread of epidemics such 
as cholera, as was the case with the demolition - in 2014-of Mensah Guinea, a poor, informal urban community in Accra (Arku, 2014).

Targeting informal activities and blighted areas of cities in Ghana, decongestion and consequent evictions have not deterred street traders and informal economic activities nor the movement of poor migrants into poor, urban, informal settlements (Steel et al., 2014; Asiedu and Agyei-Mensah, 2008). On the contrary, informal activities (including street trading) and the proliferation of slums and informal settlements have intensified. Indeed, in 2011, the AMA and UN-Habitat identified as many as 78 settlements and pockets of slums within the Accra metropolis, with over 90 per cent of these in mature stages of development and accounting for around 38 per cent and 16 per cent of the total population and city area of Accra, respectively (AMA, 2011). While the policy of urban decongestion has been implemented for the past two decades, not enough studies have been undertaken to assess the issues of the policy responses to informality. Using the existing literature, media reports and the authors' previous, extensive study of Accra, this chapter attempts to fill this knowledge gap. It questions the policy of decongestion in both theoretical and practical terms as a means of promoting the sustainable and inclusive urban development of large Ghanaian cities such as Accra. The chapter is structured into five parts. Following the introduction, it situates urban congestion within urban theory, followed by an analysis of urban growth and the development of informality in Accra. This is followed by a discussion of the effects of decongestion, and the chapter finally concludes with the policy implications of the study, particularly with respect to the right to the city and the promotion of inclusive and sustainable development in Ghana.

The decongestion policy as defined and practiced in major Ghanaian cities, particularly Accra, is at odds with and challenges recent international slogans on promoting inclusive urban development centred on the 'right to the city' theory. This is because, as Brown $(2013,957)$ notes, 'the right to the city has evolved as a powerful rallying cry in the struggle against the exclusionary processes of globalisation and the commodification of urban space, and in conflicts over who has claim to the city and what kind of city it should be. Coined by the French Marxist philosopher and sociologist Henri Lefebvre in 1967 in response to the rise of capitalist urbanisation, the theory is described as a type of human right, a collective right of all city inhabitants to participate in the use 
and production of urban space (Kuymulu, 2013a, 2013b; Harvey, 2008; World Social Forum, 2005). Decongestion thus represents an attempt by city authorities to hold on to the status quo and to define who has claims to the city and how it should be produced and used, and what kind of city it should be - core issues that the right to the city challenges.

Although the concept of the right to the city has also been criticised and challenged for its normative development agenda, which lacks in-depth analysis of actual political, economic, social and cultural contexts (Centner and Rojas, 2011; Jenkins et al., 2007) and overlooks underlying economic processes that perpetuate poverty and exclusion (Mayer, 2009; Fernandes, 2007), the concept has nevertheless created a vital platform for the introduction of a rights-based perspective on urban development (Brown et al., 2010). This rights-based perspective promoted by the right to the city concept holds significant implications for informal urban economies, such as street hawking, and slum developments. This is because street traders and residents of slums are highly dependent on contested urban public spaces, and their frequent dispossession through decongestion exercises carried out by city authorities in favour of other interests arguably leads to social exclusion of this section of the urban population. Huchzermeyer (2010) in employing the right to the city notion demonstrates how, in South Africa, the shack dwellers' movement Abahlali baseMjondolo in Durban invokes a Lefebvrian notion of the right to the city while embarking on rights-based action as one of several approaches it employs. Walsh (2013) also demonstrates the use of the right to the city by social movements in South Africa as having a liberalising effect as well as subverting the social antagonisms inherent in capitalism.

Some have argued that the concept of the right to the city has become intractably (and contradictorily) intertwined with the advance of the neo-liberal agenda in recent years (Brown, 2013; Harvey, 2008, 2012), with negative consequences for the urban poor. According to Harvey $(2012,13)$, the neo-liberal agenda has had a long-lasting and generally disastrous effect on the urban poor-the right to the city as it is now constituted is far too narrowly confined, in most cases in the hands of small political and economic elites who are in the position to shape the city more and more according to their own particular heart's desire. It is within these arguments that objectives of the decongestion policy and the right to the city concept tend to converge For example, neo-liberal policies introduced in Ghana and other sub-Saharan African countries in the 1980 s as part of the World Bank/IMF's Structural Adjustment Programmes have led to increased competition for valuable and well-located land, in which the interests of affluent and powerful groups tend to prevail over 
those of poor communities (Grant, 2009, 2015; Fumtim, 2010; Huchzermeyer, 2010; Owusu, 2008). These policies reflect the national and city governments' desire to turn African cities into globally competitive cities. For that purpose, they tend to prioritise investments in 'world-class' infrastructure that is expected to attract foreign investors, international corporations, highly qualified professionals and tourists. These efforts to increase urban competitiveness materialise through 'urban renewal' or 'beautification' initiatives involving the demolition of informal settlements and the removal of informal street trade and unauthorised structures. Like many African capital cities, Accra has followed the same pattern by adopting an entrepreneurial approach to urban governance in which the role of the state is to facilitate private sector growth (Gillespie, 2016a; Obeng-Odoom, 2013; Grant 2009).

This view is asserted by the former mayor of Accra, Alfred Okoe Vanderpuije, who swore to transform Accra into a modern, business-friendly 'Millennium City' (Obeng-Odoom, 2013), evident from his oft-quoted catchphrase: 'eyes have not seen, neither has it entered into the ears of men, what man is about to see in Accra' (Okwuosah, 2012). Thus, in June 2009, when the AMA launched the decongestion policy to remove hawkers, illegal structures and squatter settlements from the central business district (СBD), the mayor justified the exercise with the view that 'all cities in the world are aiming at beauty and modernity so as to attract tourists, investors and other business activities' and decongestion is necessary to prevent Accra being left behind in his race for excellence (Gillespie, 2016a, 2016b). However, it needs to be stressed that most right to the city advocates condemn forced evictions and any form of criminalisation of informal settlement dwellers. Instead, they strive for recognition of urban informality, be it in the area of housing or employment and the urban economy, as the best available option for millions of people despite its obvious imperfections (Afenah, 2010, 165; Parnell and Pieterse, 2010, 153).

Again, in Ghana and elsewhere in the developing world, most urban dwellers, particularly the poor, have no legal rights in the ownership and commodification of urban spaces. The majority of them do not own land; they stay in 'encroached areas' and dwell in rented shacks. In many cases, city authorities have been repetitively unwilling to upgrade these slums, because to the authorities these urban residents are a nuisance in the urban space, and they thus deny them - especially street traders and slum dwellers — rights to space. This aligns with the Lefebvrian conception of the right to the city, wherein he argues that the right to the city is a call for the establishment of rights to include sections of the urban populace who have been denied, rather than prioritising those who already possess power, such as key political and financial interests (Marcuse, 2012; Mayer, 2012). 


\section{Urban Growth and the Development of Informality in Accra}

A key feature of Ghana's urbanisation process to date is the unbalanced and skewed distribution of the urban population in favour of large cities that are perceived to offer a variety of livelihood opportunities (Owusu and OtengAbabio, 2015; Obeng-Odoom, 2013; Grant, 2009). Although Ghana had an urbanisation level of almost $5^{1}$ per cent in 2010, the administrative regions of Greater Accra and Ashanti regions, have urban population levels of 90.5 per cent and 6o.6 per cent, respectively. These two regions host the two largest cities in Ghana-namely, Accra and Kumasi. Accra and its metropolitan region, referred to as the Greater Accra Metropolitan Area (GAMA), was home to over 3.6 million people in 2010, representing around 15 per cent of Ghana's total population (see Table 9.1). Table 9.1 gives the impression that the Accra Metropolis is de-urbanising. However, as strongly argued in Owusu and OtengAbabio (2015), it has for the past two decades been fragmented into new, smaller local government areas. They add that 'this is against the backdrop of increasing land and housing prices and the process of gentrification already underway in many parts of the city - which continuously push the population to the surrounding municipalities. Under these conditions, census data are likely to give a false impression of a city undergoing depopulation' (Owusu and Oteng-Ababio, 2015, 321).

TABLE 9.1 Population of GAMA, 1970-2010

\begin{tabular}{|c|c|c|c|c|c|c|c|}
\hline \multirow{2}{*}{ District } & \multirow{2}{*}{$\begin{array}{c}1970 \\
\text { Pop. }\end{array}$} & \multicolumn{2}{|c|}{1984} & \multicolumn{2}{|c|}{2000} & \multicolumn{2}{|c|}{2010} \\
\hline & & $\begin{array}{l}\text { Growth } \\
\text { rate (\%) }\end{array}$ & Pop. & $\begin{array}{l}\text { Growth } \\
\text { rate }(\%)\end{array}$ & Pop. & $\begin{array}{l}\text { Growth } \\
\text { rate (\%) }\end{array}$ & Pop. \\
\hline Accra Metropolis & 636,667 & 3.0 & 969,195 & $3 \cdot 3$ & $1,658,937$ & 1.1 & $1,848,614$ \\
\hline Ledzokuku-Krowor & - & - & - & - & - & - & 227,932 \\
\hline Ga District* & 66,336 & $4 \cdot 9$ & 132,786 & 8.9 & $55^{0,468}$ & 5.0 & 908,053 \\
\hline Tema Metropolis & 102,431 & 4.4 & 190,917 & 2.8 & 298,432 & 3.0 & 402,637 \\
\hline Ashaiman Municip. & 22,549 & 5.8 & $5^{0,918}$ & 6.8 & $15^{0,312}$ & 2.4 & 190,972 \\
\hline Adenta Municip. & - & - & - & - & - & - & 78,215 \\
\hline Total & 827,983 & $3 \cdot 5$ & $1,343,816$ & $3 \cdot 9$ & $2,501,196$ & 3.8 & $3,656,423$ \\
\hline
\end{tabular}

* Includes Ga East, Ga West and Ga South Municipalities.

SOURCE: DERIVED FROM POPULATION CENSUS REPORTS 1970, 1984, 2000 AND 2010 (OWUSU, 2013) 
The concentration of population in the GAMA is directly linked to migrants' strong perception that the urban centre offers better economic livelihood opportunities relative to other urban centres (Awumbila et al., 2014). Once a small coastal settlement in Ghana (then called Gold Coast), Accra became very prominent following the relocation of the national administrative capital from Cape Coast to the town in 1877 by the British colonial administrators. In the view of many analysts (Asamoah, 2001; Konadu-Agyemang, 2001; Songsore, 2009; Obeng-Odoom, 2011; Owusu and Oteng-Ababio, 2015), the relocation of the national capital to Accra, followed by significant and continuous public and private investments in its infrastructure and services throughout the colonial and postcolonial periods, has served to enhance the development of the city by attracting population, businesses and capital (including direct foreign investments).

According to Owusu and Oteng-Ababio $(2015,320)$, the high concentration of population in the national capital has resulted in a spillover of its population to the surrounding districts and the rapid conversion of once rural settlements into one, big, contiguous urban agglomeration referred to as the GAMA. This rapid transformation of the GAMA region has occurred with jobs and other economic opportunities such as markets and public services remaining largely within the Accra metropolis and the surrounding municipalities largely serving as dormitory centres. Consequently, there is a large demand on the services and infrastructure of the Accra metropolis, which in addition to its resident population is estimated to attract, daily, a daytime population of over 3.5 million for various socio-economic activities (Owusu, 2008). Unable to provide adequate formal housing and employment to both its permanent resident population and migrants, informality has become the order of the day for Accra. Consequently, the informal sector is the largest provider of housing, employment and other socio-economic opportunities in Accra and a critical sector for the survival of individuals and households within the city. However, the large informal sector of the city has evolved within the context of urban planning and a governance regime that are both weak, and city authorities have come to largely regard the sector as a nuisance in terms of location and operation (GoG/MLGRD, 2012). As a city, planning has failed to adequately deal with informality, and much housing and many informal businesses have tended to be haphazardly located and not in conformity with any planning regulations. This situation has largely formed the basis for the implementation of the decongestion exercises in Accra and other major cities of Ghana. Nevertheless, Accra remains the city where the decongestion policy has been widely practiced by city authorities, possibly as a result of the magnitude of urban challenges and the intense process of urbanisation (see Figure 9.1). 


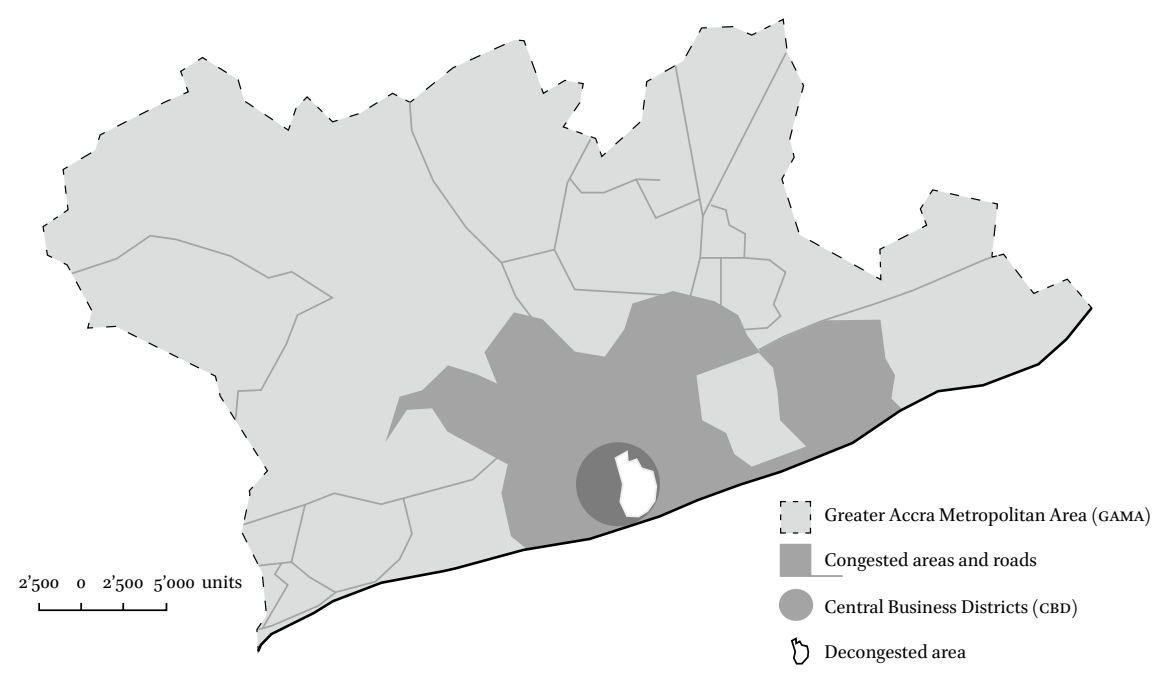

FIGURE 9.1 Map of the GAMA showing the СвD and decongested areas. (Even though decongestion occurs almost everywhere in the GAMA, we focus on areas where such activities are rampant.)

SOURCE: AUTHOR, WITH LAND USE AND SPATIAL PLANNING AUTHORITY DATA

The implementation of the decongestion policy in Accra has taken what this chapter describes as a bulldozing approach, where a violent and impulsive stance is taken with regard to slum dwellers and workers in the informal economy, especially street hawkers. To implement the policy in 2009, the AMA passed a by-law outlawing street trading and established a Special Task Force to deal with recalcitrant street traders. The Special Task Force is also mandated to deal with all activities relating to 'illegal' occupation of space in the city. In recent years, the AMA has gone further, deploying state security agenciesespecially the police - to deal with slum clearance and unauthorised occupation of public spaces (ISSER, 2014). To date, the policy of decongestion has been exercised by razing and burning unauthorised structures and chasing hawkers away from streets and sidewalks where a large number of informal economy operators eke out a living. The approach of dispossessing the informal proletariat suggests in explicit and implicit terms that certain categories of the city's workers and residents have no place in Accra to scratch out a livingan approach that advocates of the right to the city theory are very strongly critical of. For instance, stalls at the Spintex Road in Accra were set ablaze by officials from AMA as part of the city authorities' measures to beautify the city 
of Accra ahead of the visit in 2009 of the former US President Barrack Obama (Obeng-Odoom, 2011).

A number of researchers have also elaborated on how the implementation of the decongestion policy in Accra has been found to be tantamount to cruel, inhuman or degrading treatment, particularly when carried out with violence or with discriminatory intent (Onuoha, 2014; Steel et al., 2014; Abrokwah, 2013; Broadbent, 2012). During forced evictions, people are frequently harassed or beaten and occasionally subjected to inhumane treatment. For example, based on his interview with a street hawker, Gillespie (2016b, b974) explains how a trader's refusal to let the Special Task Force confiscate his stock resulted in his being beaten and sustaining severe injuries leading to him falling into a coma. Indeed, the Ghanaian media is replete with reports of the abuse of street traders and informal operators by the Special Task Force ${ }^{1}$

The decongestion of Accra's СвD also causes substantial losses for people who work in the informal economy, who usually lose goods, property, and income and suffer various inconveniences. According to Bob-Milliar and ObengOdoom (2011) in their study 'The informal economy is an employer, a nuisance, and a goldmine: Multiple representations of and responses to informality in Accra, Ghana, almost all traders interviewed claimed that they had lost 'something'; however, when the authors asked them to quantify their losses, they could not do so, preferring rather to stress the qualitative aspect of the loss, such as this inability to pay for their children's education. This assertion by traders of the loss of their capital and goods is thoroughly corroborated by other researchers (see Asiedu and Agyei-Mensah, 2008; Broadbent, 2012; Abrokwah, 2013; Onuoha, 2014; Steel et al., 2014) as well as media reportages.

While forced evictions have a detrimental impact on all, women often tend to be disproportionately affected and must withstand the worst of the abuse during forced evictions. This is because women tend to have a special place in the Ghanaian informal sector, a place that predates the contemporary era. According to Owusu and Lund (2004), though Ghanaian women have long been active in informal trading, the effects of economic reform programmes beginning in the mid-1980s have pushed more women into the informal sector, either as the sole providers or as supplementers of household incomes within the context of rising prices with regard to basic needs, growing unemployment

1 See photo archive : 'AMA used "crude tactics" to eject traders- Accra mayor', http://www .ghanaweb.com/GhanaHomePage/NewsArchive/AMA-used-crude-tactics-to-eject-traders -Accra-mayor-518311?gallery=1 and the article (2010) 'My men did not attack trader- AMA Boss', Ghana Web, https://www.ghanaweb.com/GhanaHomePage/NewsArchive/My-men -did-not-attack-trader-AMA-Boss-195269 (accessed on 3 September 2017). 
and underemployment of male partners, declining real incomes and the growing need to meet local levies on social amenity provision in the form of user charges. Robertson (1995) adds that under these conditions, the necessity for households to have female supplementary income has become imperative and women's income-generating activities have become indispensable for family survival. This is illustrated in the work of Gillespie (2016a, 71), in the form of remarks made by one hawker, Oboye, who observed bitterly that obeying the bylaw of the AMA that forbids street trading is simply not possible when one has a family to feed. Gillespie (2016a, 71) further explains that hawkers complain that the Special Task Force prevents them from making a living, vandalises their possessions, extorts bribes and sexual favours and tends to be excessively violent with traders who disobey the by-law on street trading.

Finally, the implementation of the decongestion policy has come with some political costs for both city and national leaders because of the ad hoc nature of the exercise and the lack of focus regarding the results. It is therefore no wonder that the exercise tends to be suspended during election years and only resumes after elections. In many cases, opposition parties tend to side with the informal operators while ruling national governments side with their appointed city mayors. ${ }^{2}$ There is also evidence to show that even within the ruling party tensions tend to rise when city mayors embark on decongestion exercises. A case in point is the recent suspension of the ruling party's Member of Parliament Carlos Ahinkorah by the Tema Metropolitan Assembly following his criticism of the decongestion exercise ordered by the Assembly. ${ }^{3}$ Similar criticisms have been levelled against former mayors of Accra, as the incumbent government sees their actions as detrimental to the election campaigns and as the potential cause of lost votes in the national polls. Within this political context, street traders and slum dwellers have mobilised against forced evictions using various strategies, including demonstrations and disobedience. For example, according to Brown et al. (2010), the Ghana trade union movement is collaborating with StreetNet International, a global network of informal workers' membership organisations, to organise traders' associations into a coordinated network that is capable of lobbying the state for the right to space in the city. These developments demonstrate how Accra's informal proletariat is taking collective action to claim its 'right to the city' (see Lefebvre

2 See the article (2009) 'Don't politicize Accra decongestion exercise-Ama boss', Ghana Web, https://www.ghanaweb.com/GhanaHomePage/regional/Don-t-politicize-Accra-deconges tion-exercise-AMA-boss-163014 (accessed on 9 May 2018).

3 See the article (2017) 'TMA suspends Carlos Ahenkorah over alleged misbehavior', gbcghana .com, http://www.gbcghana.com/1.11288767 (accessed on 1o September 2017). 
1996 [1967]) by defending its collective access to urban space. However, the implementation of the decongestion policy has had mixed success in keeping the informal proletariat off the streets and away from the slums. For example, the Joy FM 6 p.m. news of April 21, 2011 reported that hawkers were back on the streets doing business less than a day after a decongestion exercise was carried out. And in cases where evictions have been successful, such as the demolition of slums, evictees have moved to other squatter settlements on undeveloped land in the city. A typical case is the slum that has recently sprung up along the Accra-Tema highway-many of its inhabitants were previously residents of a section of the Old Fadama slum destroyed recently by the city authorities.

Gillespie (2016b, 989) is of the view that 'the AMA is engaging in violent processes of dispossession in order to enclose the urban commons and expel the informal proletariat'. The use of task forces in urban development exhibits a sizable level of authoritarian control in urban management as discussed above. Indeed, the use of force to dispossess the informal proletariat of urban space illustrates the influence of powerful elites in urban management, which needs to be taken into consideration in the process of urban management. We therefore are of the view that the decongestion policy in Accra is simply a disguised policy formulated and pursued by city authorities as a form of bulldozing approach of the slum clearance to undermine the presence of the poor in the city and to determine who lives and stays in the city of Accra.

Across many parts of the developing world, countries are undergoing rapid demographic transformation involving the shift of the population from rural to urban areas (Satterthwaite and Mitlin, 2014). In these countries, the pace and the recent character of the process have overwhelmed national and city governments. Consequently, in the absence of adequate preparations to cater for new and old residents of cities, individuals and households respond by addressing their needs-such as the need for housing, employment, health, education and other service delivery—by adopting a 'do-it-yourself-approach' (ISSER, 2014). However, many such approaches adopted by urban residents do not conform to city regulations and laws transplanted from the planning regulations of colonial governments, such as Ghana's antiquated Town and Country Planning Ordinance, passed in 1945, which is drawn from the pages of the British Town and Country Planning Act Ordinance of $193^{2}$ (KonaduAgyemang, 2001, 541). This planning ordinance (CAP 84) centred around planning schemes, layouts and (more importantly) minimum plot sizes has guided 
the planning of Ghanaian towns for decades, and was only revised recently with the passage of the new Spatial Planning Bill in 2016.

For Accra, city authorities have conceived decongestion as a measure for addressing some of the ills of the urban development of the city. It needs to be stressed that in reality the measure is a simple attempt to conceal the inefficiencies of the city authorities as well as the poor planning and governance of the city over the years. In other words, with the probable backlash against a slum-clearance approach firmly in mind, city authorities have coined the term 'decongestion' as a simplistic approach to clearing areas of the city of Accra they perceived as undesirable. In simpler terms, there is only a rhetorical difference between a decongestion policy and slum clearance, but no difference in practical terms. Yet it is important that city authorities understand that the informal economy is not an irregularity but linked to the urban space.

In the absence of proper urban planning, largely due to weak institutions and weak enforcement of development controls, informality has come to be seen as a nuisance to urban development. Yet, this is the sector on which many urbanite Ghanaians depend for jobs, housing and other livelihood opportunities. Decongestion seems to have in some sense facilitated a hijacking of the right to the city concept by a few individuals located within the confines of the AMA who determine whose priorities and interests require attention and what the future of Accra should look like. We share the view of Brown (2013) that although the slogan 'the right to the city' seems to appeal to a broad-based constituency, transforming it into practice will remain tentative until it is embedded in the national and local systems of spatial organisation and social justice of a developing-country city such as Accra.

\section{References}

Abrokwah, S. (2013) Decongesting the Streets of Accra: The Problems and Prospects, unpublished MPhil dissertation (Accra: University of Ghana).

Afenah, A. (2010) 'Reclaiming Citizenship Rights in Accra, Ghana', in A. Sungranyes and C. Mathivet (eds), Cities for All: Proposals and Experiences toward the Right to the City (Santiago: Habitat International Coalition), pp. 155-68.

AMA (Accra Metropolitan Assembly) (2011) Slum Situation Analysis Report Participatory Slum Upgrading and Prevention: Millennium City of Accra, Ghana (Nairobi: UN Habitat).

Arku, J. (2014) 'AMA demolishes structures at Mensah Guinea', Graphic Online, http:// graphic.com.gh/news/general-news/30153-ama-demolishes-structures-at-mensah -guinea.html, (Accessed on 13 August 2017). 
Asamoah, A.K. (2001) Depeasantization of Africa's Rural Economy: The Ghanaian experience (Accra: CAF).

Asiedu, A.B. and S. Agyei-Mensah (2008) 'Traders on the Run: Activities of Street Vendors in the Accra Metropolitan Area, Ghana', Norwegian Journal of Geography 62(3), pp. 191-202, DOI: 10.1080/00291950802335806.

Awumbila, M., G. Owusu and J.K. Teye (2014) Can Rural-urban Migration into Slums Reduce Poverty? Evidence from Ghana, Migrating Out of Poverty Working Paper 13 (Brighton: University of Sussex).

Bob-Milliar, G. M. and F. Obeng-Odoom (2011) 'The Informal Economy is an Employer, a Nuisance, and a Goldmine: Multiple Representations of and Responses to Informality in Accra, Ghana', Urban Anthropology and Studies of Cultural Systems and World Economic Development, 40 (3-4), pp. 263-84.

Broadbent, E. (2012) Research-based evidence in African policy debates. Case study 1. Decongestion in Accra, Ghana, Evidence based policy development network (EBPDN), https://www.odi.org/sites/odi.org.uk/files/odi-assets/publications-opin ion-files/9119.pdf (accessed on 9 May 2018).

Brown, A. (2013) 'The Right to the City: Road to Rio 2010', International Journal of Urban and Regional Research, 37(3), pp. 957-971, DOI: 10.1111/1468-2427.12051.

Brown, A., M. Lyons and I. Dankoco (2010) 'Street traders and the emerging spaces for urban voice and citizenship in African cities', Urban Studies, 47(3), pp. 666-683, DOI: $10.1177 / 0042098009351187$.

Centner, R. and C. Rojas (2011) Recombinant geographies of citizenship: Differentiations of the 'right to the city' in Sao Paulo, Caracas, and Buenos Aires, Proceedings of the International RC21 Conference 2011 on: The struggle to belong; Dealing with diversity in 21st century urban settings, Amsterdam, 7-9 July 2011.

Fainstein, S.S. (2010) The Just City (Ithaca: Cornell University Press).

Fernandes, E. (2007) 'Constructing the Right to the City in Brazil', Social and Legal Studies 16(2), pp. 201-219, DOI: 10.1177/og64663907076529.

Fumtim, J. (2010) 'Building Cities for and by the People: The Right to the City in Africa', in A. Sungranyes and C. Mathivet (eds) Cities for All: Proposals and Experiences toward the Right to the City (Santiago: Habitat International Coalition), pp. 195-200.

Gillespie, T. (2016a) 'Accumulation by Urban Dispossession: Struggles over Urban Space in Accra, Ghana', Transactions of the Institute of British Geographers, 41(1), pp. 66-77, DOI: 10.1111/tran.12105.

Gillespie, T. (2016b) 'From Quiet to Bold Encroachment: Contesting Dispossession in Accra's Informal Sector', Urban Geography, DOI: 10.1080/02723638.2016.1191792.

Grant, R. (2015) Africa: Geographies of Change (Oxford: Oxford University Press).

Grant, R. (2009) Globalizing City: The Urban and Economic Transformation of Accra, Ghana (Syracuse, NY: Syracuse University Press). 
GoG (Government of Ghana)/MLGRD (Ministry of Local Government \& Rural Development) (2012) National Urban Policy Framework and Action Plan (Accra: MLGRD).

Harvey, D. (2012) Rebel Cities: From the Right to the City to the Urban Revolution (London: Verso).

Harvey, D. (2008) 'The Right to the City', New Left Review, 53, pp 23-40, https://newleft review.org/II/53/david-harvey-the-right-to-the-city (accessed on 9 May 2018).

Huchzermeyer, M. (2010) 'The Policy Context for Informal Settlements: Competitiveness, Slum Eradication and a Right to the City?', Trialog, 104(1), pp. 25-8.

ISSER (Institute of Statistical, Social and Economic Research) (2014) Ghana Social Development Outlook. (Accra: ISSER).

Jenkins, P., H. Smith and Y. Wang (2007) Planning and Housing in the Rapidly Urbanising World (Oxon: Routledge).

Konadu-Agyemang, K. (2001) The political Economy of Housing and Urbanization in Africa: Ghana's Experience from Colonial Times to 1998 (Westport CT: Praeger).

Kuymulu, M.B. (2013a) 'The Vortex of Rights: 'Right to the City' at a Crossroads', International Journal of Urban and Regional Research 37(3), pp. 2013 923-40, DOI: 10.1111/1468-2427.12008.

Kuymulu, M.B. (2013b) 'Reclaiming the Right to the City: Reflections on the Urban Uprisings in Turkey',. City, 17(3), pp. 274-278, DOI: 10.1080/13604813.2013.815450.

Lefebvre, H. (1996 [1967]) The Production of Space, translated by D. Nicholson-Smith (Malden: Blackwell).

Marcuse, P. (2012) 'Whose right(s) to what city?', in N. Brenner, P. Marcuse and M. Mayer (eds) Cities for People, Not for Profit: Critical Urban Theory and the Right to the City (Oxon: Routledge), pp. 24-41.

Mayer, M. (2012) 'The 'Right to the City' in Urban Social Movements', in N. Brenner, P. Marcuse and M. Mayer (eds.), Cities For People, Not for Profit: Critical Urban Theory and the Right to the City (Oxon: Routledge), pp. 63-85.

Mayer, M. (2009) 'The 'Right to the City' in the Context of Shifting Mottos of Urban Social Movements', City, 13(2-3), pp. 362-374, DOI: 10.1080/13604810902982755.

McGranahan, G., D. Schensul and G. Singh (2016) 'Inclusive Urbanization: Can the 2030 Agenda be delivered without it?', Environment and Urbanization, 28(1), 13-34, DOI: 10.1177/0956247815627522.

McGranahan, G., P. Jacobi, J. Songsore, C. Surjadi and M. Kjellén (2001) The Citizens At Risk: From Urban Sanitation to Sustainable Cities (London: Earthscan).

Obeng-Odoom, F. (2013) Governance for Pro-Poor Urban Development: Lessons from Ghana, (Routledge, Abingdon).

Obeng-Odoom, F. (2011) 'The Informal Sector in Ghana under Siege', Journal of Developing Societies 27, pp. 355-92, DOI: 10.1177/0169796X1102700406. 
Okwuosah, U. (2012) 'AMA is doing a good job-Accra mayor Alfred Vanderpuije', Ghana Business \& Finance, 15, pp. 18-23.

Onuoha, D. (2014) 'Decongesting Accra', Johannesburg Salon, 7(1), pp. 123-130, http:// jwtc.org.za/resources/docs/salon-volume-7/TheSalon_Vol7.pdf (accessed on 30 August 2017).

Owusu, G. (2013) 'Coping with Urban Sprawl: A Critical Discussion of the Urban Containment Strategy in a Developing Country City, Accra', Planum: The Journal of Urbanism 26(1), pp. 1-17, http://www.planum.net/planum-magazine/cities-to -be-tamed/conference-proceedings (accessed on 10 August 2017).

Owusu, G. (2008) 'Indigenes' and Migrants' Access to Land in Peri-urban areas of Accra', International Development Planning Review, 30, pp. 177-198, DOI: 10.3828/ idpr.30.2.5.

Owusu, G. and R. Lund (2004) 'Markets and Women's Trade: Exploring their Role in District Development in Ghana', Norwegian Journal of Geography, 58(3), pp. 113-124, DOI: $10.1080 / 00291950410002313$.

Owusu, G. and M. Oteng-Ababio (2015) 'Moving unruly contemporary urbanism toward sustainable urban development in Ghana by 2030', American Behavioural Scientists (ABS) 59(3), pp. 311-327, DOI: 10.1177/0002764214550302.

Parnell, S. and E. Pieterse (2010) 'The "Right to the City": Institutional Imperatives of a Developmental State', International Journal of Urban and Regional Research, 34(1), pp. 46-62, DOI: 10.1111/j.1468-2427.2010.00954.x.

Robertson, C. (1995) 'Comparative advantage: Women in trade in Accra, Ghana and Nairobi, Kenya', in B. House-Midamba and K.E. Ekechi (eds.), African Market Women and Economic Power (London: Greenwood Press), pp. 99-119.

Satterthwaite, D. and D. Mitlin (2014) Reducing Urban Poverty in the Global South (London: Routledge).

Schmid, C. (2012) 'Henri Lefebvre, the Right to the City, and the New Metropolitan Mainstream' in N. Brenner, P. Marcuse and M. Mayer (eds.) Cities for People, Not for Profit: Critical Urban Theory and the Right To The City (Oxon: Routledge), pp. 42-59.

Songsore, J. (2009) The Urban Transition in Ghana: Urbanization, National Development and Poverty Reduction (London: IIED).

Stanek, L. (2011) Henri Lefebvre on Space: Architecture, Urban Research, and the Production of Theory. (Minneapolis: University of Minnesota Press).

Steel, W.F., T.D. Ujoranyi and G. Owusu (2014) 'Why Evictions Do Not Deter Street Traders: Case Study in Accra, Ghana', Ghana Social Science Journal, 11(2), pp. 52-76.

UNFPA (United Nations Population Fund) (2007) UNFPA State of World Population 2007: Unleashing the Potential of Urban Growth. (New York: UNFPA).

Walsh, S. (2013) “'We won't Move": The Suburbs Take back the Center in Urban Johannesburg', City 17 (3), pp. 400-408, DOI: 10.1080/13604813.2013.795330.

World Social Forum (2005) World Charter for the Right to the City, http://www.right tothecityplatform.org.br/download/publicacoes/World\%2oCharter\%2ofor\%2o the\%2oRight\%2oto\%2othe\%2oCity.pdf (accessed on 9 May 2018). 